\title{
Awareness of Rational Medication Use and Antibiotic Self- Medication Practices among Undergraduate Students in a University in Sri Lanka
}

\author{
Chaminie B Gunawardhana $^{1 *}$, MHF Sakeena ${ }^{1}$ and C Sivayoganthan ${ }^{2}$ \\ ${ }^{1}$ Department of Pharmacy, Faculty of Allied Health Sciences, ${ }^{2}$ Department of Agriculture Extension, Faculty of Agriculture, \\ University of Peradeniya, Peradeniya, Sri Lanka
}

*For correspondence: Email: chamini101@yahoo.com; Tel: +94-75-9673266, +94-81-3999624

Received: 15 May 2014

Revised accepted: 27 February 2015

\begin{abstract}
Purpose: To evaluate the practice of self-medication and evaluate the knowledge of rational use of antibiotics among undergraduate students of University of Peradeniya, Sri Lanka.

Method: A cross-sectional, recall study was conducted among the university student population who practice self-medication in the study location. Stratified, random sampling technique was used to distribute 246 questionnaires in eight faculties of the institution. The response rate was $71 \%$, and 175 completed questionnaires were analyzed to determine significant differences and correlation with different variables.

Results: A majority of the study sample were females (54\%), aged 23 - 25 years (46.9\%). The most frequently used antibiotic was amoxicillin (95.4\%). Common cold with fever was the disease condition treated by a large majority (84.9\%). Knowledge on dose, frequency, duration and side-effects of antibiotics among students was moderate, with a mean value of $58.3 \%$. There was a significant difference in knowledge on antibiotics between health science and non-health science students although no significant difference was observed in knowledge with respect to gender, academic year and family income.

Conclusion: Antibiotic consumption was associated with students' academic background. This study highlights the need for interventions to assure rational use of antibiotics.
\end{abstract}

Keywords: Antibiotics, Self-medication, Rational use, Undergraduate students, Awareness

Tropical Journal of Pharmaceutical Research is indexed by Science Citation Index (SciSearch), Scopus, International Pharmaceutical Abstract, Chemical Abstracts, Embase, Index Copernicus, EBSCO, African Index Medicus, JournalSeek, Journal Citation Reports/Science Edition, Directory of Open Access Journals (DOAJ), African Journal Online, Bioline International, Open-J-Gate and Pharmacy Abstracts

\section{INTRODUCTION}

Self-medication implies rapid and direct access to treatment as well as self-involvement of an individual in relieving minor ailments [1]. However, practice of self-medication for prescription only medicine such as antibiotics becomes a real issue in the aspects of safe and efficacious use of medicines. Overuse and misuse of antibiotics, including practice of selfmedication, is particularly a serious issue worldwide due to development of resistance for antimicrobials which is largely associated with consumption patterns of antimicrobials [2-4]. Antibiotic resistance is considered a global threat due to reasons such as increased morbidity and mortality rates due to uncontrolled infectious diseases as the standard treatments become ineffective [5-8].

Knowledge about treatment options, availability, affordability and accessibility to treatments are 
common determinants of features and extent of antibiotic self-medication practice in developing countries $[9,10]$. Several published reports highlight the self- medication practice of antibiotics agents among students involved in higher education [11-16]. Global tendency is observed to use antibiotics without a proper prescription such that it is estimated that more than $50 \%$ of antibiotics are purchased without a proper prescription [17]. It has been evident with a study conducted by Wolffers in 1987 that practice of self-medication exists in Sri Lankan community for a long time, irrespective of the legal framework which prohibits dispensing antibiotics without prescription $[18,19]$.A previous report from University of Peradeniya in 2012 highlights the self-medication practices among 250 undergraduate students in Medicine, Pharmacy, Nursing, Dental Sciences, and Veterinary Science [20]. In the same report, it was revealed that $78.8 \%$ of the study sample practice self-medication and antibiotics account for $13 \%$ of frequently used drugs and the study highly recommended further investigations on antibiotic self-medication practice among university student population in Sri Lanka. The objective of the present study was to evaluate pattern of antibiotic self-medication practice and to determine the extent of awareness of rational use of antibiotics among undergraduates in University of Peradeniya.

\section{EXPERIMENTAL}

Location of the present study is: University of Peradeniya situated in Kandy district of the Central Province, Sri Lanka. More than 10170 students were studying in the year 2011, in eight faculties of different disciplines namely, Agriculture, Allied- Health Sciences (AHS), Art, Dental Sciences, Engineering, Medicine, Science and Veterinary Science [21]. Allied- Health
Sciences (AHS), Dental Sciences, Medicine and Veterinary Science are regarded as health science faculties and the other faculties are regarded as non-health science faculties. Pharmacy, Nursing, Medical Laboratory Sciences, Physiotherapy and Radiography degree programs are conducted in the Faculty of AHS.

\section{Study design}

The population of this study was defined as the undergraduates who were practicing selfmedication of antibiotics, in the University of Peradeniya. The study was a descriptive, crosssectional study which used a questionnaire as the tool of data collection. It was a recall study so that the participants had answered the questions on consumption of antibiotics with their experience in the past six months before commence of the study. Stratified, proportionate, random samples were selected from the target population which was estimated as $13 \%$ of the total number of students in the university, based on the results of a previous study [20]. Selected sample size was 246 and 175 questionnaires were analyzed as mentioned in Table 1.

\section{Data collection tool}

A structured questionnaire was prepared to collect data, covering demographic and socioeconomic variables (part A) including age, gender, family income, course of study and academic year of study. It was also composed of questions covering different views on the practice of antibiotics self-medication (part B and C) such as types of antibiotic use, dose taken, duration of use and expected side effects. The questionnaire was translated into two languages: Sinhala and Tamil.

Table 1: Stratified sample of participants

\begin{tabular}{lccccc}
\hline Faculty & $\begin{array}{c}\text { Total number } \\
\text { of students } \\
\text { (2011 statistics) }\end{array}$ & $\begin{array}{c}\mathbf{1 3} \% \text { of the total } \\
\text { number of } \\
\text { students } \\
\text { (target population) }\end{array}$ & $\begin{array}{c}\mathbf{2 0} \% \text { of the } \\
\text { target } \\
\text { population }\end{array}$ & $\begin{array}{c}\text { No of } \\
\text { Adjusted } \\
\text { value of } \\
\text { the sample }\end{array}$ & $\begin{array}{c}\text { questionna } \\
\text { ires used } \\
\text { for } \\
\text { analysis }\end{array}$ \\
\hline $\begin{array}{l}\text { Agriculture } \\
\text { Allied Health }\end{array}$ & 925 & 120 & 24 & 25 & 23 \\
Sc. & 685 & 89 & 18 & 20 & 20 \\
Arts & 3730 & 485 & 97 & 50 & 38 \\
Dental Sc. & 380 & 49 & 10 & 12 & 12 \\
Engineering & 1655 & 215 & 43 & 45 & 28 \\
Medicine & 1222 & 159 & 32 & 34 & 25 \\
Science & 1725 & 224 & 45 & 48 & 17 \\
Veterinary & 388 & 50 & 10 & 12 & 12 \\
Total & 10710 & 1391 & 279 & 246 & 175 \\
\hline * & & & & & \\
\hline
\end{tabular}

\footnotetext{
*Source: reference number 21
} 


\section{Ethical issues}

Ethical clearance was granted before the study from the Evaluation Subcommittee of the Ethical Review Committee, Faculty of Medicine, University of Colombo. Permission was granted in writing also by the Vice Chancellor of the University of Peradeniya to collect data from the undergraduate student population. An information sheet and a consent form were attached to every questionnaire. The verbal consent was obtained from each participant before distributing the questionnaires.

\section{Collection of data}

Each faculty was personally visited by the researcher to collect data. Participants were selected from groups of 3-6 students spending the time leisurely in the faculty premises. Among the students those who mentioned that they practice self-medication with antibiotics within the past six months, every other student was selected into the study sample. The purpose of the survey and its scientific value was explained to each participant through a small discussion.

\section{Inclusion criteria}

Undergraduate students of University of Peradeniya those who practiced antibiotic selfmedication.

\section{Exclusion criteria}

Clergymen and non-cooperative students

\section{Assessment of knowledge on antibiotics}

Participants were questioned on five aspects regarding antibiotics: use of antibiotics for a viral disease (common cold), dose (strength), and frequency, duration of the antibiotics and sideeffects of the antibiotic written by participants. The answers were analyzed with respect to the facts given in Australian Medicine Handbook 2011 [22] and ranked as correct/partially correct/incorrect/not answered. Consequently, five variables were defined for five aspects of knowledge.

The variables were re-constructed into different variables to assess level of knowledge such that "correct" was equal to "good" and correspond for 3 marks, "partially correct" was equal to "moderate" and carried 2 marks, "incorrect" or "not answered" was equal to "poor" and corresponded for 1 mark. Then a single variable was computed covering knowledge on dose, frequency, duration and side effects and named as total knowledge. The level of total knowledge on antibiotic consumption was considered "good" for score 10-12, "moderate" for score 7-9 and score 1-6 was considered as "poor". Means of scores on total knowledge were calculated. Significant differences in the level of knowledge among different student groups based on gender, course of study, academic year and family income level were statistically assessed by t-test.

\section{Analysis of data}

The overall response in data collection was $71.14 \%$. The SPSS (Statistical Package for Social Sciences) version 20 was used for data analysis. Chi-square test and t-test were used for statistical analysis.

\section{RESULTS}

Distribution of gender, age, academic year and family income in the sample

More than half of the study samples were females accounting for $54 \%$. Considering the overall population majority are female students and also in each faculty except Engineering [22]. This is reflected in results of the study as well.

Higher proportion of the participants belonged to the category 23 to 25 years of age accounting for $46.9 \%$ while $37.7 \%$ of the participants were lower than or equal to 22 years of age. Out of all the participants, $93.7 \%$ had mentioned their age. Proportion of students belong to first year, second year, third year, fourth year and fifth year were $31.8 \%, 22.5 \%, 18.5 \%, 26.6 \%$ and $0.6 \%$ respectively. The total percentage of the students mentioned their academic year was $98.8 \%$.

Based on the information provided by the students approximate monthly income by their family members was Sri Lanka Rs. 36563.3 with a range of Rs. 2000 to Rs. 160000 . Only 150 students $(85.7 \%)$ had mentioned their family income.

\section{Knowledge on use of antibiotics for common cold and fever}

Only a total of 13 students $(7.4 \%)$ had mentioned that common cold and fever was not treated with antibiotics as it was viral in origin.

More than two third of the students $(85.1 \%)$ mentioned that they consumed antibiotics for 
Table 2: Significant descriptive data on use of antibiotics for self- medication: Commonly used antibiotics, dosage forms and disease conditions treated

\begin{tabular}{lcc}
\hline Description & Frequency & $\%$ \\
\hline Commonly used antibiotics & 166 & 94.9 \\
Amoxicillin & 29 & 16.6 \\
Erythromycin & 11 & 6.3 \\
Cephalexin & 11 & 6.3 \\
Cloxacillin & & \\
Capsules & 137 & 80.1 \\
Tablets & 116 & 67.8 \\
Creams & 36 & 21.1 \\
Other (solutions/lotions/syrups) & 10 & 5.8 \\
Common cold and fever & & \\
Cough & 146 & 84.9 \\
Sore-throat & 86 & 50 \\
Diarrhoea and skin diseases & 46 & 26.7 \\
Commonly & 24 & 14 \\
\hline
\end{tabular}

common cold and fever (Table 2). Response rate was $88 \%$.

Higher percentage of health science students (18.84\%), compared to non-health science students $(0 \%)$ were knowledgeable that antibiotics are not consumed for common cold and fever, at $95 \%$ confidence interval $\left(x^{2}=\right.$ $21.574 ; \mathrm{df}=1 ; p<0.001)$.

Knowledge on dose, frequency, duration of the course and side-effects

Out of 121 students who had answered the relevant question, $33.7 \%$ were able to provide the accurate dose for the antibiotic used by them. Among all the students, $4.6 \%$ were able to provide a partially correct value for dose of the antibiotic used by them when the answers were compared with facts in the Australian Medicines Handbook (Table 3).

Higher proportion (46.3\%) of students had mentioned that duration of antibiotic course was supposed to be 3-4 days or 10 days while only $16.6 \%$ believed that antibiotics should be taken for 5 days (Table 3 ). It was the belief of $18.3 \%$, out of 143 , that the antibiotics should be taken for less than 3 days or until cured.

\section{Total knowledge of antibiotics}

It was found that almost one third of health science students $(30.4 \%$ ) had a "good" (score = 10-12) knowledge of antibiotics while only $4.7 \%$ of non-health science students had a good knowledge of antibiotics. The knowledge level was "moderate" (score $=7-9$ ) in $47.8 \%$ of health science students and $40.6 \%$ of non-health science students. It was revealed that $54.7 \%$ of non-health science students had "poor" (score = $1-6)$ knowledge while only $21.7 \%$ of health science students scored poorly.

\section{Correlation of awareness with variables}

Chi square test was performed to find out correlations with gender, course of study (i.e. health science or non-health science), year of study and income vs. different variables giving information on self-medication.

Table 3: Knowledge on use of antibiotics

\begin{tabular}{|c|c|c|c|c|c|c|c|c|}
\hline \multirow{3}{*}{$\begin{array}{l}\begin{array}{l}\text { Aspect of knowledge } \\
\text { tested }\end{array} \\
\text { Strength of the drug }\end{array}$} & \multicolumn{8}{|c|}{ Response (N, \%) } \\
\hline & \multicolumn{2}{|c|}{$\begin{array}{c}\begin{array}{c}\text { Correct } \\
(\%)\end{array} \\
\end{array}$} & \multicolumn{2}{|c|}{$\begin{array}{c}\text { Partially correct } \\
(\%)\end{array}$} & \multicolumn{2}{|c|}{$\begin{array}{c}\text { Incorrect } \\
(\%)\end{array}$} & \multicolumn{2}{|c|}{$\begin{array}{c}\text { Not answered } \\
(\%)\end{array}$} \\
\hline & 59 & $(33.7)$ & 8 & $(4.6)$ & 54 & $(30.9)$ & 54 & $(30.9)$ \\
\hline Frequency of the drug & 105 & $(60.0)$ & 18 & (10.3) & 31 & (17.7) & 21 & (12.0) \\
\hline $\begin{array}{l}\text { Duration of the course in } \\
\text { days }\end{array}$ & 29 & (16.6) & 81 & $(46.3)$ & 32 & (18.3) & 33 & (18.9) \\
\hline $\begin{array}{l}\text { Possible } \\
\text { side -effects }\end{array}$ & 20 & $(11.4)$ & 8 & $(4.6)$ & 27 & $(15.4)$ & 120 & ( 68.6) \\
\hline
\end{tabular}


Table 4: Summary of correlation with gender and study group

\begin{tabular}{|c|c|c|c|c|c|c|}
\hline \multirow{2}{*}{$\begin{array}{l}\text { Description of } \\
\text { variables on } \\
\text { knowledge }\end{array}$} & \multirow{2}{*}{ Value } & \multicolumn{3}{|c|}{ Level of Knowledge } & \multirow[t]{2}{*}{ Total } & \multirow[t]{2}{*}{$\mathrm{Cl}(95 \%)$} \\
\hline & & Poor & Moderate & Good & & \\
\hline \multicolumn{7}{|c|}{$\begin{array}{l}\text { Duration of antibiotic } \\
\text { course }\end{array}$} \\
\hline Health-science & $\begin{array}{l}\text { Frequency } \\
\text { Percentage }\end{array}$ & $\begin{array}{c}14 \\
20.29 \%\end{array}$ & $\begin{array}{c}36 \\
52.17 \%\end{array}$ & $\begin{array}{c}19 \\
27.54 \%\end{array}$ & $\begin{array}{c}69 \\
100 \%\end{array}$ & $\begin{array}{c}X^{2}=17.83 \mathrm{df}=2 \\
P<0.001^{*}\end{array}$ \\
\hline Non health-science & $\begin{array}{l}\text { Frequency } \\
\text { Percentage }\end{array}$ & $\begin{array}{c}51 \\
48.11 \%\end{array}$ & $\begin{array}{c}45 \\
42.45 \%\end{array}$ & $\begin{array}{c}10 \\
9.43 \%\end{array}$ & $\begin{array}{c}106 \\
100 \%\end{array}$ & \\
\hline \multicolumn{7}{|c|}{$\begin{array}{l}\text { Strength of antibiotic } \\
\text { used }\end{array}$} \\
\hline Health-science & $\begin{array}{l}\text { Frequency } \\
\text { Percentage }\end{array}$ & $\begin{array}{c}28 \\
40.58 \%\end{array}$ & $\begin{array}{c}7 \\
10.14 \%\end{array}$ & $\begin{array}{c}34 \\
49.28 \%\end{array}$ & $\begin{array}{c}69 \\
100 \%\end{array}$ & $\begin{array}{c}X^{2}=24.17 \\
d f=2 P<0.001^{*}\end{array}$ \\
\hline Non-health science & $\begin{array}{l}\text { Frequency } \\
\text { Percentage }\end{array}$ & $\begin{array}{c}80 \\
75.47 \%\end{array}$ & $\begin{array}{c}1 \\
0.94 \%\end{array}$ & $\begin{array}{c}25 \\
23.58 \%\end{array}$ & $\begin{array}{c}106 \\
100 \%\end{array}$ & \\
\hline Side effects & & & & & & \\
\hline Health-science & $\begin{array}{l}\text { Frequency } \\
\text { Percentage }\end{array}$ & $\begin{array}{c}48 \\
69.57 \%\end{array}$ & $\begin{array}{c}6 \\
8.70 \%\end{array}$ & $\begin{array}{c}15 \\
21.74 \%\end{array}$ & $\begin{array}{c}69 \\
100 \%\end{array}$ & $\begin{array}{c}X^{2}=17.66 \\
d f=2 P<0.001^{*}\end{array}$ \\
\hline Non-health science & $\begin{array}{l}\text { Frequency } \\
\text { Percentage }\end{array}$ & $\begin{array}{c}99 \\
93.40 \%\end{array}$ & $\begin{array}{c}2 \\
1.89 \%\end{array}$ & $\begin{array}{c}5 \\
4.72 \%\end{array}$ & $\begin{array}{c}106 \\
100 \%\end{array}$ & \\
\hline Duration of course & Frequency & & 44 & & & \\
\hline & Percentage & $35.00 \%$ & $\begin{array}{c}44 \\
55.00 \%\end{array}$ & $10 \%$ & $100 \%$ & $\mathrm{df}=2 \mathrm{P}=0.040^{*}$ \\
\hline Female & $\begin{array}{l}\text { Frequency } \\
\text { Percentage }\end{array}$ & $\begin{array}{c}37 \\
38.90 \%\end{array}$ & $\begin{array}{c}37 \\
38.90 \%\end{array}$ & $\begin{array}{c}21 \\
22 \%\end{array}$ & $\begin{array}{c}95 \\
100 \%\end{array}$ & \\
\hline
\end{tabular}

Table 5: Summary of statistical data on marks for knowledge on antibiotics

\begin{tabular}{|c|c|c|c|c|c|c|c|}
\hline Criteria compared & $\bar{N}$ & Mean & $\begin{array}{c}\text { Std. } \\
\text { deviation }\end{array}$ & $\begin{array}{l}\text { Std. error } \\
\text { of Mean }\end{array}$ & $\begin{array}{c}\mathrm{t}-\mathrm{value} \\
\mathrm{Cl}=95 \%\end{array}$ & df & P-value \\
\hline \multicolumn{8}{|l|}{ Gender } \\
\hline Male & 80 & 7.08 & 2.04 & 0.22 & 0.022 & 173 & 0.983 \\
\hline Female & 95 & 7.09 & 2.29 & 0.23 & & & \\
\hline \multicolumn{8}{|l|}{ Academic year } \\
\hline First and second year & 94 & 6.90 & 1.98 & 0.20 & 1.358 & 171 & 0.176 \\
\hline Third year or above & 79 & 7.35 & 2.38 & 0.27 & & & \\
\hline \multicolumn{8}{|l|}{ Academic course } \\
\hline Health science & 69 & 8.12 & 2.20 & 0.26 & 5.432 & 173 & $0.000^{*}$ \\
\hline Non-health science & 106 & 6.42 & 1.88 & 0.18 & & & \\
\hline \multicolumn{8}{|l|}{ Income level } \\
\hline Low (< Rs 36500) & 86 & 6.91 & 2.20 & 0.24 & 1.283 & 148 & 0.201 \\
\hline $\begin{array}{l}\text { Moderate or high } \\
\text { (> Rs 36500) }\end{array}$ & 64 & 7.38 & 2.21 & 0.28 & & & \\
\hline
\end{tabular}

* Statistically significant

The study revealed that at $95 \%$ confidence level, percentage of health science students with a good knowledge on duration of the antibiotic course, strength of the antibiotic used and possible side-effects was significantly higher than that of non-health science students as depicted in Table 4. It was revealed that more females $(22 \%)$ were well-aware about the duration of antibiotic course than males (10\%) (Table 4).

\section{Knowledge of antibiotics among different groups of students}

Total knowledge on dose (strength), frequency, course duration and side-effects were tested to identify significance of differences with respect to gender, course of study (health vs non-health), academic year of study and income. It was revealed that the mean of total knowledge score of all participants was 7.09 with a minimum of 4 and maximum of 12 . Standard deviation was 2.17. Overall, it is reasonable to mention that the knowledge on use of antibiotics among the students was "moderate" (score $=7 / 12$ ) with a value of $58.3 \%$.

The knowledge on rational consumption of antibiotics was significantly different between health science students and non-health science students at $95 \%$ confidence interval. 
However, there was no significant difference in the knowledge on rational consumption of antibiotics based on gender or academic year of study or monthly family income level (Table 5).

\section{DISCUSSION}

Self-medication is an important determinant of improper use of antibiotics [2]. Nevertheless, it remains the first choice of treatment to many communities in the world $[23,24]$. However, it is essential to assure quality and safe drug use by regulating issues such as self-medication with risk associated drug categories similar to antibiotics.

Amoxicillin $(95.4 \%)$ was the most frequently consumed antibiotics by self- medication practices $[17,20,25]$. This creates a possible threatening situation for the development of resistance to Amoxicillin. This can be aggravated with the fact that common cold and fever, which are symptoms of viral diseases was mostly treated with antibiotics agents $(84.9 \%)$, only $7.4 \%$ of the participants mentioned that common cold and fever was not supposed to be treated by antibiotics as these symptoms were due to viral infection. Further it was notified that only $12 \%$ of the participants could have completed full duration of antibiotic course. Cough was the second commonest symptom treated with antibiotics and it is also necessary to be treated with appropriate antibiotics only after proper diagnosis. This study indicates skin diseases and diarrhea were treated with antibiotics by $14 \%$ of the population studied. Consumption of antibiotics without a proper diagnosis for such diseases can sometimes be detrimental. It is also noticeable that $21 \%$ of students use antibacterial creams to treat skin diseases without being diagnosed by a physician.

The assessment of knowledge on antibiotic consumption reveals several risk factors associated with irrational use of antibiotics; consumption of antibiotics for common cold and fever, lack of knowledge on accurate dose and frequency and poor compliance to antibiotic therapy which is indirectly indicated by the lack of knowledge on duration of the antibiotic course. These factors are known to contribute for irrational use of antibiotics and development of resistance [2,3]. However, the results reveals that the health science students were more knowledgeable about rational use than nonhealth science students and it seems that health science students have a tendency to use antibiotics in a relatively accurate way when compared with non-health science students. This is similar to a finding from a study in Mangalore,
India, which revealed that antibiotics account for $34 \%$ of the drug used in self-medication among tertiary students and also found out the study population had sufficient knowledge on adverse effects as they were medical students [14]. Lack of knowledge on antibiotics was also identified in a study from Accra, Ghana which revealed that $49 \%$ of the students had poor knowledge about the medical implications of irrational use of antibiotics and $46 \%$ of the students did not comply with the full antibiotic course [11].

Based on risk factors identified from results the recommendations can be made for interventions on enhancing awareness about antibiotics and resistance and introducing standard therapeutic guidelines. A study from Thailand revealed a successful model to reduce irrational antibiotic consumption which was a multidisciplinary approach for the issue of antibiotic resistance development due to irrational use [26]. It is worth to consider adopting the same model to Sri Lanka where unnecessary antibiotic consumption is observed for common cold and fever.

\section{Limitations of the study}

Response rate of the study was limited to $71.1 \%$. The descriptive, cross-sectional method was applied due to time constraints. The results are subjected to limitations associated with a selfadministered questionnaire based survey.

\section{CONCLUSION}

Self-medication with antibiotic agents is prevalent among undergraduate students at University of Peradeniya. Thus, antibiotic resistance among studied population can increase due to the misuse or overuse of these medicines. This study highlights possible predisposing factors for development of resistance to antimicrobial medicines and the emerging need of interventions to enhance the awareness on rational usage of antibiotics.

\section{REFERENCES}

1. Geneva: World Health Organization. Guidelines for Regulatory Assessment of Medicinal Products for use in Self Medication. WHO/EDM/QSM/00.1.31p. 2000. [cited 2012 August 04]. Available from: http://apps.who.int/medicinedocs/pdf/s2218e/s2218e. pdf

2. Holloway K, Dijk LV. World medicine situation 2011: rational use of medicine. Gineva:World Health Organization 2011; 3(1). [cited 2012 August 04]. Available from: 
http://apps.who.int/medicinedocs/documents/s18062e $n / s 18062 e n . p d f$.

3. Okeke IN, Lamikanra A, Edelman R. Socioeconomic and behavioral factors leading to acquired bacterial resistance to antibiotics in developing countries. Emerg Infect Dis 1999; 5(1): 18-27.

4. Apisarnthanarak A, Mundy LM. Correlation of antibiotic use and antimicrobial resistance in Pratumthani, Thailand, 2000 to 2006. Am J Infect Control 2008; 36(9): 681-682.

5. Hart CA, Kariuki S. Antimicrobial resistance in developing countries. BMJ 1998; 317 (7159): 647-650.

6. Carmeli $Y$, Troillet $N$, Karchmer AW, Samore MH. Health and economic outcomes of antibiotic resistance in Pseudomonas aeruginosa. Arch Intern Med 1999; 159(10): 1127-1132.

7. Ehinmidu JO. Antibiotics susceptibility patterns of urine bacterial isolates in Zaria, Nigeria. Trop J Pharm Res 2003; 2 (2): 223-228.

8. McGowan JE. Economic impact of antimicrobial resistance. Emerg Infect Dis 2001; 7(2): 286-292.

9. Radyowijati A, Haak H. Determinants of Antimicrobials use in Developing countries. Child Health Research Project Special Report. Maryland: Johns Hopkins University Office on Design and Publications; 2002, 4: 4-6. [cited 2012 August 04]. Available from: http://www.harpnet.org/doc/AMR_vol4.pdf

10. Sarahroodi S, Arzi A, Sawalha AF, Ashtarinezhad A. Antibiotics self-medication among Southern Iranian university students. Int J Pharmacol 2010; 6(1): 4852.

11. Donkor ES, Tetteh-Quarcoo PB, Agyeman IO, Nartey P. Self-medication practices with antibiotics among tertiary level students in Accra, Ghana: a crosssectional study. Int. J. Environ. Res. Public Health 2012; 9: 3519-3529.

12. Abay SM, Amelo W. Assessment of self-medication practices among Medical, Pharmacy and health science students in Gondar University, Ethiopia. J Young Pharm 2010; 2 (3): 306-310

13. Fadare JO, Tamuno I. Antibiotic self-medication among university medical undergraduates in Northern Nigeria. J Public Health Epidemiol 2011; 3(50): 217 220.

14. Badiger S, Kundapur R, Jain A, Kumar A, Pattanshetty S, Thakolkaran N, Bhat N, Ullal N. Self-medication patterns among medical students in South India. Australas Med J 2012; 5(4): 217-220.
15. Olayemi OJ, Olayinka BO, Musa Al. Evaluation of antibiotic self- medication pattern among undergraduate students in Ahmadu Bello University (Main Campus), Zaria. Res J Appl Sci Eng Technol 2010; 2(1): 35-38.

16. Osemene KP, Lamikanra A. A study of prevalence of self- medication practice among university students in Southwestern Nigeria. Trop J Pharm Res 2012; 11(4):683-689.

17. Togoobaatar G, lkeda N, Ali M, Sonomjamts $M$, Dashdemberel S, Mori R, Shibuya K. Survey of nonprescribed use of antibiotics for children in an urban community in Mongolia. Bull World Health Organ. 2010; 88: 877-953.

18. Wolffers, I. Drug Information, Sales Practices in Some Pharmacies in Colombo, Sri Lanka. Soc Sci Med 1987; 25 (3): 319-321.

19. Ministry of Justice. Cosmetic, Devices and Drug Act No: 27 of 1980. [cited 2013 December 12]. Available from: http://www.lawnet.lk/section.php?file=http://www.lawn et.lk/docs/statutes/stats_1956_2006/indexs/Vol2/198 oYOVOC27A.html

20. Kumarathunga RMST. Assessment of self-medication practices among health sciences related students in University of Peradenitya [dissertation]. [ Peradeniya]:University of Peradeniya $2010 \mathrm{Jul} ;$ p 40.

21. University of Peradeniya. Statistical Handbook 2011: Peradeniya: University of Peradeniya 2012; pp 26,32,35,3

22. Rossi S, editor. Australian Medicines Handbook 2011. Adelaide: Australian Medicines Handbook Pty Ltd; 2011: $p p$ 114,122, 127.

23. Santo EGE, Floury B, Cisse $M$. What determines the choice of health care treatment in the town of Contonou (Benin)? Bull World Health Organ 1998; 76(2): 195-201.

24. Le TH, Ottosson E, Nguyen TKC. Drug use and selfmedication among children with respiratory illness or diarrhea in a rural district in Vietnam: a qualitative study. J Multidiscip Healthc 2011; 4: 329-336.

25. Sarahroodi S, Arzi A. Self- Medication with antibiotics: Is it a Problem among Iranian College Students in Tehran? J. Biol. Sci 2006; 8(9): 829-832.

26. Sumpradit N, Chongtrakul P, Anuwong K, Pumtong S, Kongsomboon $K$, Butdeemee $P$, Khonglormyati J, Chomyong S, Tongyoung $P$, Losiriwat $S$ et al. Antibiotics smart use: a workable model for promoting the rational use of medicines in Thailand. Bull World Health Organ 2012; 90: 905-913. 